\title{
INTEGRATION OF PASTURE, FODDER AND CATTLE IN COCONUT SMALL HOLDINGS
}

\author{
L V K Liyanage, H P S Jayasundera, D T Mathes and \\ D N S Fernando*
}

\begin{abstract}
A farming system was established in a 45 year old coconut plantation at Rathmalagara Estate, Madampe, in the North Western Province of Sri Lanka. The main objective of this study was to evaluate the performance of an integrated farming system in relation to coconut production and productivity of land.

Results inclicate that there has been no adverse effect on coconut and copra production clue to the establishment of the integrated system. The substitution of inorganic fertilizer mainly nitrogen and partly phosphorus and potassium through the integration of animals, fodder and pasture system did not affect the critical levels of nutrients in coconut leaves of treatment plots. Furthermore, feed supply through pasture/fodder in the system was adequate for cattle throughout. In terms of animal performance the average live weight gains were $306 \mathrm{~g} / \mathrm{head} /$ day at the end of the first year. The most remarkable feature was that the integrated system reduced the cost of inorganic fertilizer for coconut by $69 \%$, thus reducing the cost of production of coconut. Based on the overall results it is suggested that the integrated system is more productive and beneficial than a monoculture system to coconut small holdings.
\end{abstract}

\section{$\underline{\text { Introduction }}$}

The coconut sector in Sri Lanka has $86.6 \%$ of the holdings less than 2.02 ha (5 acre) group, while less than 0.8 ha ( 2 acre) group absorbs the major share of $58.2 \%$ (Census of Agriculture, 1982).

The current practices recommended for coconut holdings to maximise production are largely through a system of chemical farming which may be appropriate for estates, but not for small holdings. The limited funds and other constraints such as risks due to crop losses and fluctuating prices by the small holders often discourage them to apply chemical inputs. It has been estimated

that the cost of application of inorganic fertilizer and cultural practices constitute $64 \%$ and $13 \%$ respectively of the total expenditure on maintaining one hectare of small holding (Liyanage, 1986). Thus any technology developed to reduce expenditure on fertilizer and cultural practices would be of considerable benefit to the small holder. A feasible approac $h$ to achieve this goal is through the integration of pasture/fodder and cattle in coconut small holdings.

*Sri Lanka Council for Agricultural Research Policy and Coconut Research Institute, Lunuwila, Sri Lanka, respectively. 
Pasture studies done at the Coconut Research Institute have shown that there has been no adverse effect on nut production provided both crops are adequately fertilized and grown in the favourable rainfall areas. In fact, with Brachiaria species there has been a long term beneficial effect on nut production (Santhirasegaram, 1966). Therefore an integrated farming system was established under a 8.0 ha plot of coconut in order to evaluate its performance and, to demonstrate its adaptability especially to small holders. This model was designed to increase the coconut production and productivity of land by introducing the pasture/fodder/cattle system. The major considerati6n in formulating this system was to reduce the expenditure to the bare minimum and to make the system ecologically sound and economy viable.

\section{$\underline{\text { Materials and Methods }}$}

The experiment was started in October, 1985 at Rathmalagara Estate, Madampe situated in the Wet Intermediate rainfall zone. The mean annual rainfall and its distribution over a period of 30 years are shown in Figure 1. (Mean annual temperature of the site was around 26.9,C). The soil type was Red Yellow Podzolic soll (Ultisol). The plantation consisted of 45 year old Ordinary Tall coconut palms planted at a distance of $8.4 \times 8.4 \mathrm{~m}$ giving a density of $137 \mathrm{palms} / \mathrm{ha}$.

The model included six paddocks with 24 coconut palms in each. One of these paddocks served as the control, where the palms only received inorganic fertilizer at the rate of $3 \mathrm{~kg} / \mathrm{palm} /$ year of Coconut Adult Palm Mixture and dolomitic limestone at the rate of $1.5 \mathrm{~kg} / \mathrm{palm}$ once in 3 year. No cultural operations were done except the usual rounds twice year. The other five padclocks, in addition to these practices, were planted with a mixture of Leucaena leucocephala, Gliricidia sepium and a grass legume mixture of Brachiaria miliiformis/Pueraria phaseoloides.

The lay-out for a single paddock is shown in Figure 2. Leucaena was planted in two rows along the coconut avenue at a spacing of $2.0 \times 1.0 \mathrm{~m}$ giving a density of 16 trees/coconut square (250/trees/ ha). The mixture of B. milifformis and Pueraria phaseoloides was established in alternate rows $60 \mathrm{~cm}$ apart in the remaining area of these paddocks. Along the bounclary fence Gliricidia and Leucaena were planted alternately at $1.0 \mathrm{~m}$ apart. Coconut in these five paddocks were fertilized at the rate of $0.75 \mathrm{~kg}$ of muriate of potash and $0.18 \mathrm{~kg}$ of saphos phosphate per palm annually. A mixture of urea, saphos phosphate and murlate of potash in equal proportions (at the rate of $25 \mathrm{~kg} / \mathrm{ha}$ each) was applied to the grass legume mixture at the time of planting.

One year after the establishment of above crop components, animal component consisting of four Jersey $\mathrm{x}$ Local cross bred helfers at six months of age were introduced to the model. At the beginning of the grazing cycle, animals were tethered to four palms of the paddock in the row-A and allowed to graze the grass/ legume available around the palm. During the night animals were tethered closely to the palm in order to allow dung and urine to drop within the manure circles. On the second day animals were moved to the next four palms in row B. This rotational grazing cycle in the 5 paddocks was completed after 30 days. The animals were then transferred to the first paddock to repeat another grazing cycle. This rotation enable the cattle to be tethered to each palm for 12 days per year and allow a 30 day period for the grass/legume mixture to regenerate.

In addition to free grazing with grass and legume mixture at the rate of around $35 \mathrm{~kg}$ of fresh matter/head/day, the cattle were fed with loppings of Gliricidia and Leucaena at $2 \mathrm{~kg}$ of fresh matter/head/day and with time it increased up to $5 \mathrm{~kg}$ of fresh matter/head/day. Towards the end of monsoon and during the drought periods, animals were allowed to graze only for few hours depencling on the feed availability and for the rest of the time they were kept tethered to the palms. During these periods urea treated rice straw (4 kg urea dissolved in 100 litres of water and mixed to $100 \mathrm{~kg}$ of straw) was fed ad lib supplemented with 750-1000 of (dry weight) of Gliricidia/Leucaena leaves. At first straw was given at the rate of $4 \mathrm{~kg} / \mathrm{head} / \mathrm{day}$ and later it was increased up to $10 \mathrm{~kg}$. Rotation of 
animals frorn palm to palm and from paddock to paddock continued cluring this period too. At all times, animals had ready access to drinking water. A commercial mineral mixture ( $\mathrm{Ca}$ and $\mathrm{P}$ in 2:1 ratio) was supplied at the rate of $30 \mathrm{~g} / \mathrm{head} / \mathrm{day}$ along with drinking water. In order to assess the efficiency of this feeding systern, the animals were weighed at weekly intervals. To assess the amounts to nutrients returned to each coconut palm through cowdung and urine, records were kept throughout the period. To evaluate the effects of the rotational grazing system on coconut production and copra yields, records on number of nuts and copra weight per palm were kept at each pick.

\section{$\underline{\text { Results and Discussion }}$}

\section{Nut and copra yield}

Nut and copra yields of palms per year as affected by the pasture/fodder/animal integration are presented in Table 1. Results inclicated that both nut and copra production of the integrated system compared to the coconut monoculture systern did not have marked difference for the three years period after the establishment of model. This suggests that the integrated system is comparable to monocrop systern from the point of view of the performance of palms.

\section{Nutrient content in coconut leaves.}

Nutrient content in coconut leaves as affected by the pasture/fodder/animal integration is presented in Table 2. It was revealed that three years after the establishment of the integrated systern where inorganic fertilizer was applied to the palms at a lower level compared to the coconut monoculture system there was no drop in the critical levels of nutrients in the coconut leaves of those palms. This indicates that the integration of pasture/fodder and cattle with coconut did not affect the nutrient levels of coconut leaves.

\section{Nutrients returned through cowdung and urine}

Nutrients returned through cowdung and urine in the integrated system are shown in Table 3. It was observed that each animal had about eight urinations per day having around 2.5 litres of urine per urination and about $6 \mathrm{~kg}$ of fresh cowdung per animal daily. On the average fresh cowdung contains $0.6 \% \mathrm{~N}, 0.3 \% \mathrm{P}_{2} \mathrm{O}_{5}, 0.4 \% \mathrm{~K}_{2} \mathrm{O}$ and fresh urine contains $1.1 \% \mathrm{~N}$, and $1.5 \% \mathrm{~K}_{2} \mathrm{O}$ (CRI, 1967). Although cowdung and urine collectively returned $0.812 \mathrm{~g}$ of $\mathrm{N}, 0.2199 \mathrm{of}_{2} \mathrm{O}_{5}$ and $0.802 \mathrm{~g}$ of $\mathrm{K}_{2} \mathrm{O} /$ palm/year in the system, only a portion may be available for the coconut palm as loss of nutrients can occur through volatalization, leaching, surface runoff of water, absorption by weeds etc. Even at a $50 \%$ loss it is clearly evident that still the total nitrogen requirements can be met from the addition of urine and cowdung by the cattle in the integrated system.

\section{Performance of grass legume mixture}

Results on the dry matter production of the grass legume mixture arc given in Table 4 . The total quantity of forage available through B. milifformis and Pueraria mixture was adequate for grazing the cattle throughout wet seasons. However, total dry matter production of $26422.1 \mathrm{~kg} / \mathrm{ha}$ in 1986 was reduced $23492.7 \mathrm{~kg} / \mathrm{ha}$ towards the latter half of 1987 largely as a result of over grazing. Alternatively, Centroserna pubescens could be effectively mixed with $\underline{B}$. milifformis to form a more persistant mixed sward in the model.

\section{Biomass production from tree legumes}

Fresh yields of green matter and wood from Leucaena within the paddocks and frorn a mixture of Leucaena/Gliricidia along the fences arc presented in Table 5. During the first to fourth pruning 
cycles, lopping was done in August/September, 1986; March, 1987; August, 1987 and March, 1988, respectively almost soon after a peak rainy season. Highest wood and green biomass yields of 14, $277.1 \mathrm{~kg}$ and $11,905 \mathrm{~kg} / \mathrm{ha}$ respectively from Leucaena within paddocks were obtained in the fourth pruning Cycle. Both Leucaena and Gliricidia grown along the fences produced satisfactory green matter yields of more than $100 \mathrm{~kg} / 100 \mathrm{~m}$ fence. The low green matter yield of $54 \mathrm{~kg} / \mathrm{ha}$ produced by Leucaena in the third pruning cycle was largely due to the defoliation frorn a severe attack of Psyllid (Heterosphylla cubana) during the dry period. However, total green matter yields obtained from the two tree fodders were adequate for meeting the feed requirements of heifers throughout, especially during the dry seasons when mixed with urea treated straw.

\section{Live weight gains of animals}

The mean weekly live weight gains of heifers are shown in Figure 3. The live weights of heifers increased from an initial of around $70 \mathrm{~kg}$ to $200 \mathrm{~kg}$ at the end of the first year, giving a mean weight gain of $306 \mathrm{~g} / \mathrm{head} /$ day by feeding with pasture and fodder alone without any concentrates.

\section{Saving on the cost of inorganic fertilizer for coconut}

The amounts and cost of inorganic fertilizer applied for coconut palms in the integrated farming system are presented in Table 6 . In the coconut monoculture system, addition of $800 \mathrm{~g}$ of urea, $600 \mathrm{~g}$ of saphos phosphate and $1600 \mathrm{~g}$ of muriate of potash per palm is equivalent to Rs. 2.34, Rs. 1.24 and Rs. 4.52, respectively giving a total cost of Rs. 8.10 per palm annually. In the integrated system where the total amount of nitrogen was provided by the addition of cowdung and urine, the palms were supplemented with $180 \mathrm{~g}$ of saphos phosphate and $750 \mathrm{~g}$ of muriate of potash per palm, which is equivalent to Rs. 0.37 and Rs. 2.12 respectively giving a total cost Rs. 2.49 per palm. This mostrated that the integrated farming system with cattle resulted in a saving of $69 \%$ on the cost of inorganic fertilizer for coconut compared to the coconut monoculture system. As this system 11 as been studied only for a period of three years the long term economic benefits are yet to be realised.

\section{Conclusions}

Results of this integrated farming system clearly demonstrated that it is both technically feasible and economically viable in developing the small holdings to increase production and oulleity of land. It is encouraging that no adverse effects were shown on the coconut and copra production and on the critical levels of nutrients in coconut fronds from the palm in the integrated system compared with those in control plots. These results also indicated that substitution of inorganic fertilizer mainly iitrogen, and partly phosphorus and potassium with organic manure is very effective reducing the cost of inorganic fertilizer leading to a $69 \%$ saving on the cost of inorganic fertilization in coconut.

It was also observed that the systern could play an important role in developing a favourable soil structure and improving its fertility.

Though this model was initially developed for the use of small farmer, it could be used with considerable advantage even in large holdings. The full impact of the integration of pasture/tree fodder/cattle with coconut would of course depend much on the strength of the interactions on the researchers, policy makers and farmers.

\section{ACKNOWLEDGEMENTS}

The authours are grateful to the Director of the Coconut Research Institute for granting permission to publish this paper. We wish to express our appreciation to the technical and field staff of 
the DivIsion of Agronomy for their assistance in carrying out this work most satisfactorily. Finally, sincere thanks are due to Mr. A A D N Athauda for typing the manuscript.

\section{REFERENCES}

Census of Agriculture, 1982 Dept. of Census \& Statistics

Coconut Research Institute, Sri Lanka (1967) Leaflet No. 9. Liyanage, D V (1966) Low cost technology for the development of coconut small holdings. CORD 2 (1) : 1-11.

Santhiseragaram, K (1966) The effects of pasture on the yield of coconut. Journal of Agricultural Society of Trinidad and Tobago. $66: 183-193$.

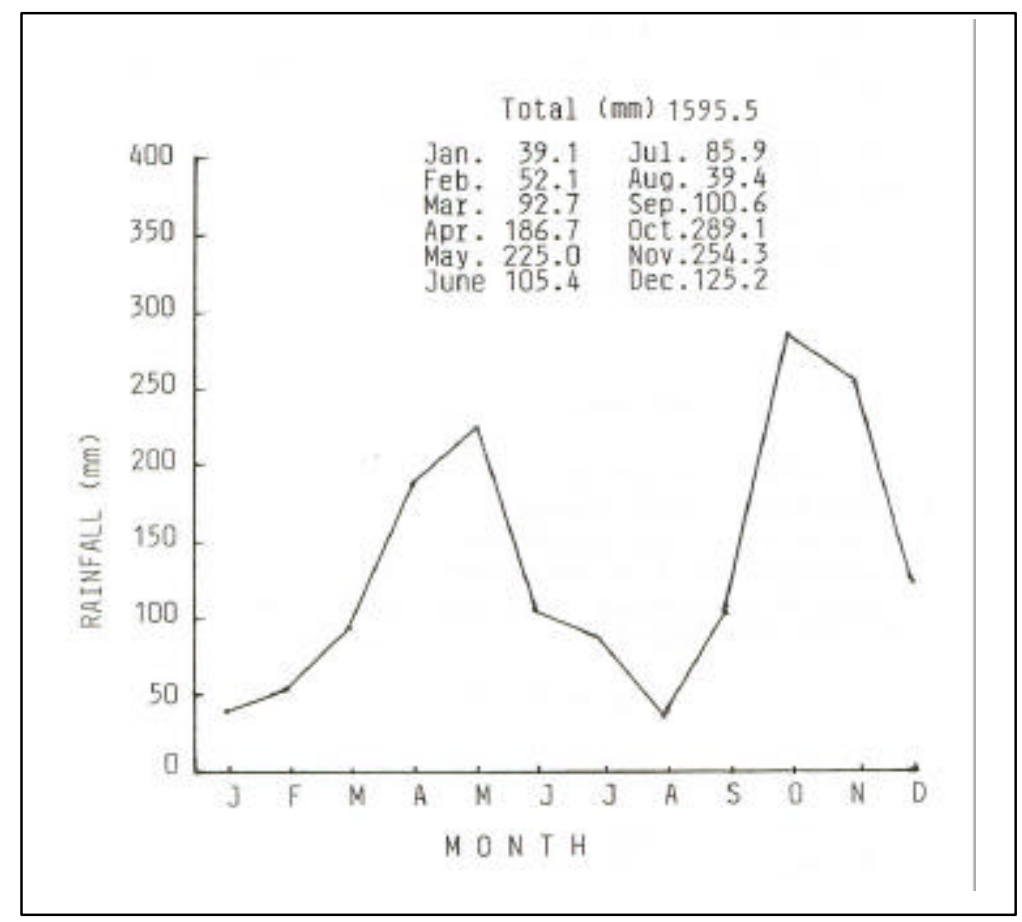

Figure 1: Average monthly rainfall (for last thirty years) at Rathmalagara Research Station, Madampe (NWP) 


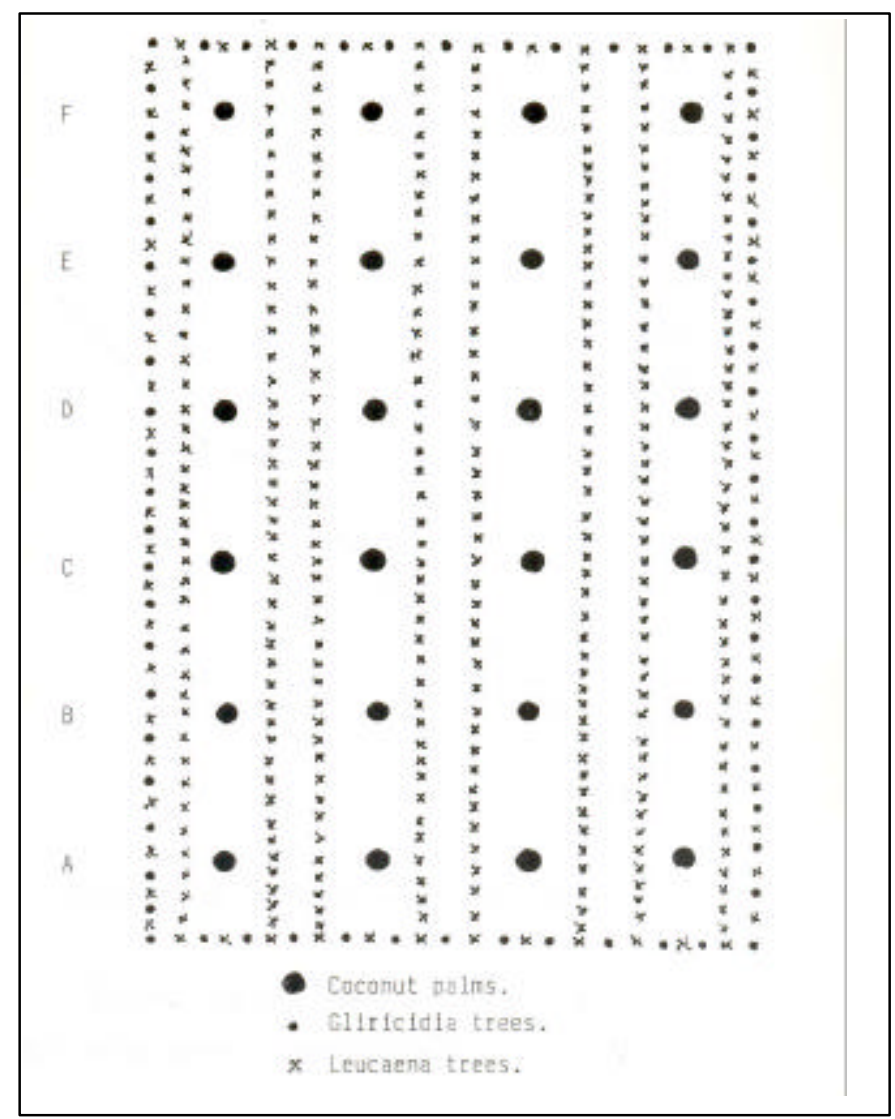

Figure 2: Schematic pattern of planting Gliricidia and Ipil-ipil with Coconut in a paddock

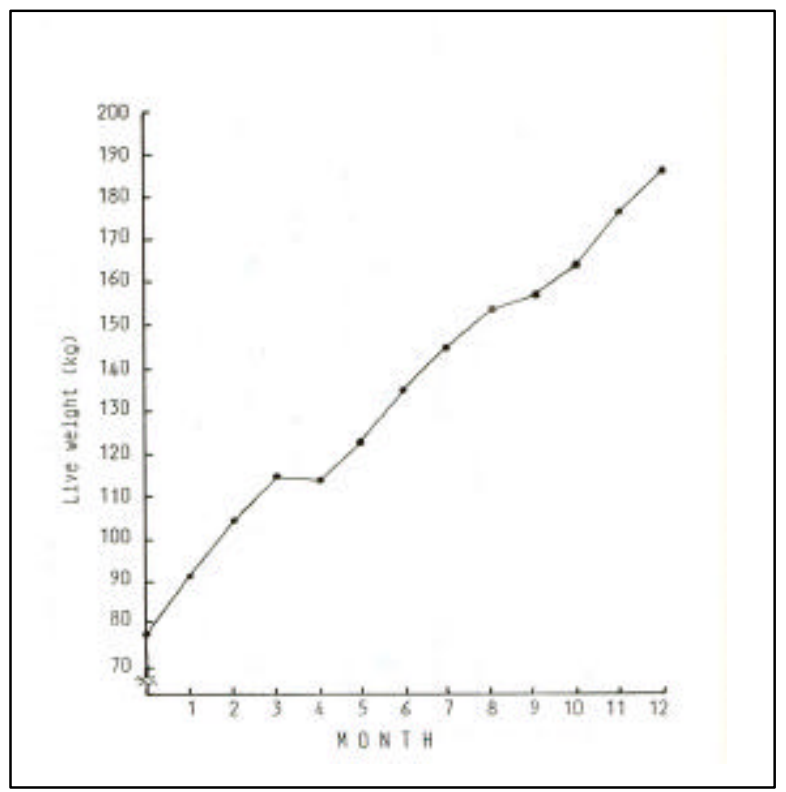

(Average weight gain-306 gm/head/day)

Figure 3: Mean live weight gain of 6 month of old heifers 
Table 1: Nut and copra yiled of palms as affected by Pasture/fodder/animal integration

\begin{tabular}{|l|c|c|c|c|c|c|}
\hline \multirow{2}{*}{ System } & \multicolumn{2}{|c|}{1986} & \multicolumn{2}{c|}{1987} & \multicolumn{2}{c|}{$1988^{*}$} \\
\cline { 2 - 7 } & $\begin{array}{c}\text { Nut } \\
\text { Yield }\end{array}$ & $\begin{array}{c}\text { Copra } \\
\text { yield }\end{array}$ & $\begin{array}{c}\text { Nut } \\
\text { Yield }\end{array}$ & $\begin{array}{c}\text { Copra } \\
\text { Yield }\end{array}$ & $\begin{array}{c}\text { Nut } \\
\text { Yield }\end{array}$ & $\begin{array}{c}\text { Copra } \\
\text { Yield }\end{array}$ \\
\hline $\begin{array}{c}\text { Integrated } \\
\text { Systems }\end{array}$ & (Nuts/ha) & (kg/ha) & (Nuts/ha) & $(\mathrm{kg} / \mathrm{ha})$ & $($ Nuts/ha) & (kg/ha) \\
$\begin{array}{c}\text { Coconut mono- } \\
\text { Culture systems }\end{array}$ & 13856 & 2678 & 12624 & 2170 & 7488 & 1499 \\
\hline
\end{tabular}

*Yield from four harvest

Table 2: Nutrient content in coconut leaves as affected By pasture/fodder/animal integrated

\begin{tabular}{|l|c|c|c|c|c|}
\hline \multirow{2}{*}{ System } & \multicolumn{5}{|c|}{ Nutrients content (\%) } \\
\cline { 2 - 6 } & $\mathrm{N}$ & $\mathrm{P}$ & $\mathrm{K}$ & $\mathrm{Ca}$ & $\mathrm{Mg}$ \\
\hline Integrated system & 2.26 & 0.18 & 1.17 & 0.44 & 0.27 \\
Coconut monoculture system & 2.25 & 0.15 & 1.20 & 0.49 & 0.25 \\
\hline $\begin{array}{l}\text { Critical levels of nutrients in } \\
\text { coconut leaves } \\
\text { (fremond et. Al 1966) }\end{array}$ & $1.8-2.0$ & 0.12 & $0.8-1.0$ & 0.50 & 0.30 \\
\hline
\end{tabular}

Table 3: Nutrient return through cowdung and urine

\begin{tabular}{|l|c|c|c|c|}
\hline \multirow{2}{*}{ Material } & Amount & \multicolumn{3}{|c|}{ Nutrients (kg/palm) } \\
\cline { 3 - 5 } & $\mathrm{Kg} /$ palm & $\mathrm{N}$ & $\mathrm{P}_{2} \mathrm{O}_{5}$ & $\mathrm{~K}_{2} \mathrm{O}$ \\
\cline { 3 - 5 } & & & & 0.219 \\
Dung & 73 & 0.438 & 0.292 \\
Urine & $34(30.41)$ & 0.374 & Tracers & 0.510 \\
\hline Total & & 0.812 & 0.219 & 0.802 \\
\hline
\end{tabular}

Table 4: Dry matter production of grass legume mixture

\begin{tabular}{|l|c|c|}
\hline \multirow{2}{*}{ Component } & \multicolumn{2}{|c|}{ Dry matter (kg/ha) } \\
\cline { 2 - 3 } & 1986 & 1987 \\
\hline Grass & 17957.6 & 18665.6 \\
Legume & 7467.5 & 2936.0 \\
Weed & 997.0 & 1891.1 \\
\hline Total & 26422.1 & 23492.7 \\
\hline Legume content in the & & \\
Mixture (\%) & 28.26 & 12.49 \\
\hline
\end{tabular}


Table 5: Biomass production (fresh yield) of tree legumes in the system

\begin{tabular}{|c|c|c|c|c|c|c|c|c|}
\hline & \multicolumn{8}{|c|}{ Pruning cycle } \\
\hline & \multicolumn{2}{|r|}{1} & \multicolumn{2}{|r|}{2} & \multicolumn{2}{|r|}{3} & \multicolumn{2}{|c|}{4} \\
\hline & Wood & Leaves & Wood & Leaves & Wood & Leaves & Wood & Leaves \\
\hline Leucaena (in nadocks) & & (Greenmatter) & & (Greenmatter) & & (Greenmatter) & & \\
\hline $\mathrm{Kg} / \mathrm{ha}$ & 12105.6 & 7188.5 & 8736.0 & 8411.5 & 13827.8 & 2695.7 & 14277.1 & 11905.0 \\
\hline $\begin{array}{l}\text { Leucaena (Along fences) } \\
\text { Kg/100 m fence }\end{array}$ & 242.5 & 144.0 & 175.0 & 168.5 & 277.0 & 54.0 & 286.0 & 238.5 \\
\hline $\begin{array}{l}\text { Gliricidia (Along fences) } \\
\text { Kg/100 m fence }\end{array}$ & 167.5 & 139.0 & 210.5 & 178.5 & 386.5 & 260.5 & 390.5 & 287.5 \\
\hline
\end{tabular}

Table 6: Amounts and cost of inorganic fertilizer applied for Coconut in the farming system

\begin{tabular}{|l|r|r|r|r|}
\hline \multirow{2}{*}{ Component } & \multicolumn{2}{|c|}{ Integrated system } & \multicolumn{2}{c|}{ Coconut monoculture } \\
\cline { 2 - 5 } & $\begin{array}{c}\text { Amount } \\
\text { (gm/palm }\end{array}$ & $\begin{array}{c}\text { Cost/ } \\
\text { Palm }\end{array}$ & $\begin{array}{c}\text { Amount } \\
\text { (gm/palm) }\end{array}$ & Cost \\
\hline & & Rs. Cents & & Rs. Cents \\
Urea & Nil & Nil & 800 & 2.34 \\
Sapos phosphate & 180 & 0.37 & 600 & 1.24 \\
Muriate of potash & 750 & 2.12 & 1600 & 4.52 \\
& & & & 8.10 \\
\hline Total & 930 & 2.49 & 3000 & 1296.00 \\
\hline Total/ha & $145.0(\mathrm{~kg})$ & 398.40 & $468(\mathrm{~kg})$ & \\
\hline
\end{tabular}

